\title{
Analyse des risques en radiothérapie
}

Ce numéro de Radioprotection publie deux articles «compagnons» de S. Thellier qui traitent de l'analyse des risques en radiothérapie. Sujet ô combien important si l'on se souvient des accidents d'Épinal (2006) et de Toulouse (2007). Dans la première partie, une transposition de la méthode d'analyse des modes de défaillance et de leurs effets (AMDEC) en radiothérapie est examinée en détail. Son application dans cette spécialité médicale est controversée. Certaines unités de radiothérapie trouvent cette méthode satisfaisante, tandis que d'autres rencontrent des difficultés. En s'appuyant sur les difficultés rencontrées dans l'application de l'AMDEC, l'auteure a développé une nouvelle méthode dénommée EPECT (Espace de Partage et d'Exploration de la Complexité du Travail) qui est basée sur l'analyse des modes de réussite plutôt que sur celle des modes de défaillance. La deuxième partie présente la méthode EPECT et les premiers résultats positifs de son application. Ces deux articles sont basés, d'une part, sur de larges revues de la littérature et, d'autre part, sur des données expérimentales collectées auprès de trois services de radiothérapie. Ces articles mettent en lumière l'importance de l'approche des sciences humaines et sociales dans l'évaluation des risques des activités de soins. Je vous invite à lire également le commentaire éditorial de M. Bulot sur le sujet de l'analyse de risques. Spécialiste en gestion des risques en milieu industriel et pratiquant depuis plus de 10 ans dans le domaine de la santé et de l'évaluation de la sécurité des patients en radiothérapie en particulier, M. Bulot propose une vision élargie des interactions entre risque et facteur humain et organisationnel. Des articles traitant de ces questions d'évaluation de risque et de sciences humaines et sociales sont à l'évidence les bienvenus dans le journal Radioprotection.

Aussi dans ce numéro et dans la continuité de notre ligne éditoriale, vous trouverez des articles variés dans tous les domaines de la radioprotection.

Enfin, je voudrais remercier chaleureusement notre collègue J. Farah qui a servi pendant cinq ans comme éditeur associé de Radioprotection. Physicien médical, J. Farah a été en charge de tous les manuscrits du domaine médical soumis à notre journal. À la suite d'une évolution professionnelle, J. Farah ne peut plus assurer la charge importante d'éditeur associé. Il restera cependant avec nous comme membre du comité de rédaction. Qu'il reçoive ici toute notre reconnaissance! Bienvenue à A. Isambert qui succède à J. Farah comme éditeur associé.

\section{Risk analysis in radiotherapy}

In this issue Radioprotection publishes two companion articles by S. Thellier on risk analysis in radiotherapy. This is a very important subject if we remember the accidents in Epinal (2006) and Toulouse (2007). In the first part, the transposition of the Failure Mode and Effects Analysis (FMEA) method into radiotherapy is examined in detail. Its application in this medical specialty is controversial. Some radiotherapy units find this method satisfactory, while others encounter difficulties. Based on the difficulties encountered in applying the FMEA method, the author developped a new method called EPECT (French acronym for spaces of sharing and exploration of the complexity of the work) which is based on the analysis of success modes rather than of failure modes. The second part presents this EPECT method and the first positive outcomes of its application. These two articles are based on extensive literature reviews and experimental data collected from three radiotherapy departments. These articles highlight the importance of the social sciences and humanities approach to risk assessment in medicine. I also invite you to read the editorial commentary of $\mathrm{M}$. Bulot on the issue of risk analysis. As an expert in risk management in industrial field with more than 10 years experiences in patient safety assessment in radiotherapy, M. Bulot proposes a broader vision of the interactions between risk and human and organisational factor. Articles on these risk assessment and social science and humanities issues are obviously welcome in the Radioprotection journal.

You can also read in this issue various articles on radiation protection in line with our editorial policy.

Finally, I would like to warmly thank our colleague J. Farah who served for five years as an associate editor of our journal Radioprotection. Medical physicist, J. Farah was in charge of all manuscripts dealing with radiological protection in the medical field. Following a professional evolution, J. Farah can no longer assume the heavy workload of associate editor. However, he will remain with us as a member of the editorial board. May he receive here all our gratitude! Welcome to A. Isambert who succeeds J. Farah as associate editor. 